\title{
Geo-electrical investigation of the groundwater potential of Ogidi and environs, Anambra State, South-eastern Nigeria
}

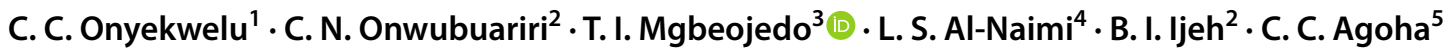

Received: 24 December 2020 / Accepted: 15 February 2021 / Published online: 1 March 2021

(c) The Author(s) 2021

\begin{abstract}
The electrical resistivity method was used to determine the groundwater potential of Ogidi and its environs. Thirteen soundings were carried out at thirteen different locations using the ABEM terrameter (SAS 1000), and adopting the Schlumberger configuration with maximum current electrode spacing of $1000 \mathrm{~m}$. The lithologic logs for the boreholes were used to delineate the geologic sections. The results revealed six to nine geo-electric layers comprising laterite, clayey sandstone, sandstone, water-saturated sandstone and shale. The water-saturated sandstone forms the aquiferous unit. This unit was found to have resistivity values ranging from $363 \Omega \mathrm{m}$ to $9107 \Omega \mathrm{m}$. It is deeply seated in some areas with a depth of $33.2-103 \mathrm{~m}$. It was observed that the hydraulic conductivity varies between 0.001 and $0.066 \mathrm{~m} /$ day, while the transmissivity values vary between 0.01 and $4.7 \mathrm{~m}^{2} /$ day. Among all the VES points studied, it was observed that VES 1 has the highest transmissivity value and the highest aquifer thickness. In view of the foregoing, it is expected that water will flow more from aquifer in VES 1 since groundwater flow from an aquifer is directly proportional to transmissivity.
\end{abstract}

Keywords Groundwater potential · Vertical electrical sounding $\cdot$ Schlumberger array · Transmissivity · Geo-electric sections $\cdot$ Nigeria

\section{Introduction}

An adequate supply of portable water is one of the prerequisites for every type of development programme. For this reason, the efforts connected with the location, development and conservation of ground water supplies are of fundamental economic importance for any country, state, local council, city, town and even community. This is particularly obvious for the arid areas of the tropical and subtropical regions where both agricultural and general development

T. I. Mgbeojedo toomgbeojedo@gmail.com

1 Department of Physics and Industrial Physics, Nnamdi Azikiwe University, Awka, Nigeria

2 Department of Physics, Michael Okpara University of Agriculture, Umudike, Nigeria

3 Geotechnical Department, Arab Center for Engineering Studies, Doha, Qatar

4 Department of Chemistry and Earth Sciences, Qatar University, Doha, Qatar

5 Department of Geology, Federal University of Technology, Owerri, Nigeria are increasingly dependent on quantity and quality of water supply. From the study of an area like Ogidi and its environs that has a temperate climate where nature has provided water in apparently sufficient quantities, the necessity to search for groundwater reserves seems to be less obvious but it does exist (Ugochukwu et al. 2015). This is because no population can survive without adequate supply of affordable and quality portable water. In the study area, water supply problems are to be expected because of the ever increasing industrialization and urbanization the area is undergoing. Moreover, according to Okwudike (2012), in less than 15 years, the population of Ogidi which is about three hundred thousand $(300,000)$, would have grown to about six-hundred thousand $(600,000)$. During a preliminary tour of the town, it was observed that many wells drilled at different places in the area have been abortive or have dried up because of the lack of prior systematic scientific investigation. Some of the existing shallow wells reflect high drawdown during the dry season (mainly November to February each year). The drawdown or outright failure of wells, as well as the inadequacy of water supply for improvement schemes, could result to acute water shortages with attendant health and economic implications. It therefore has become necessary to study the 
groundwater resource potentials of Ogidi and its environs in order to meet the projected water demand of the communities within a stipulated time frame.

Quality groundwater supplies, like every other kind of buried natural resources of the earth, are becoming progressively more difficult to locate (Keary and Brooks 1991). This owes largely to the increasing human activity resulting to the pollution of underground water sources. Accordingly, water sources located should be tested for quality, purity and satisfied for consumption.

Any new technique which will assist in the location of borehole sites and which will eliminate to a great extent the sinking of unproductive wells is of a great value. This will complement more traditional water finding methods of geology, such as modern geophysical investigation techniques that are able to locate water-bearing formations under the circumstances that are beyond the capabilities of the older conventional methods.

In principle, each of the four main methods of geophysical prospecting, i.e. the magnetic, the gravity, the seismic and the electrical methods, are capable of furnishing useful information in connection with groundwater problems when applied in areas in which the physical conditions satisfy the necessary requirements. In general, however, the seismic and the electric resistivity methods are mostly used because of their high-resolution power in respect of the particular problems encountered in prospecting for water (Bayowa et al. 2014). However, because of some factors like costeffectiveness, availability of equipment and its simplicity, the electrical resistivity method was chosen over seismic method for this study.

\section{Location and physiography}

The study area is located in Idemili North Local Government Area of Anambra State, South-east Nigeria. The climate is tropical with an average annual rainfall of $1478 \mathrm{~mm}$. The vegetation is characterized by the humid tropical rainforest belt of Nigeria. In most parts, the forests have been cleared for agriculture, industrial sites, urban development and road construction. Streams and river courses are marked by fairly thick vegetation. The survey area lies approximately between latitudes $6^{\circ} 05^{\prime} 30 " \mathrm{~N}$ and $6^{\circ} 10^{\prime} 48^{\prime \prime} \mathrm{N}$, and longitudes $6^{\circ} 49^{\prime} 00^{\prime \prime} \mathrm{E}$ and $6^{\circ} 55^{\prime} 30^{\prime \prime} \mathrm{E}$, and covers an area of about 7.4 $\mathrm{Km}^{2}$. The area is bounded in the north by Ogbunike, in the south by Umuoji, in the west by Nkpor and in the east by Abatete as shown in Fig. 1.

\section{Geological setting}

The geology of Anambra State consists of Alluvium (Holocene), Benin Formation (Miocene-Pleistocene), OgwashiAsaba Formation (Oligoocene-Miocene), the Ameki
Formation (Eocene) and Imo shale with its lateral equivalent (Paleocene). The Alluvium consists of lose sands with high percentage of quartz content. It is found along the banks at the lower ridges of the River Niger. The thickness of the deposit is tens of meters in the Onitsha area (Egboka and Okpoko 1999). The Benin Formation underlies the Alluvium. The lithology consists of thick yellow and white sands with interbedded pebbles and alternation of clays and sandy clays (Egboka and Okpoko 1999). Formation thickness is estimated to be $200 \mathrm{~m}$.

Underlying the Benin Formation is the Ogwashi-Asaba Formation. The Ogwashi-Asaba Formation which outcrops at Onitsha, Nnewi and Ihiala consists of alternation of seams of lignite with clays and shale. The thickness is about $300 \mathrm{~m}$ (Ezenwa 1998). Underlying the Ogwashi-Asaba Formation is the Ameki Formation, which consists of lignite and sandstones. The Formation thickness is estimated to be $1460 \mathrm{~m}$ (Ekwe et al. 2006). The Imo shale consists of thick clayey shale, fine textured, dark grey to bluish grey with occasional admixture of clay, ironstones and thin sandstone bands (Reyment 1965). Its sands member is the Ebenebe sandstone. The Ebenebe sandstone consists of medium to coarse-grained sandstone that forms the Ugwuoba-Ufuma-Umunze ridge. Its thickness is about $1200 \mathrm{~m}$.

Table 1 shows the summary of the geology of Anambra State, while Fig. 2 shows a reflection of the local geology of the study area.

\section{Hydrogeology of the study area}

Streams and rivers draining the study area are of two types;

1. Those that originate from outside the study area which includes River Niger and Mamu River

2. Those that originate from within the study area such as Idemili River and Ezigbo River (Madu 2009).

The Idemili River and its tributaries drain almost a quarter of the area under investigation. During the rainy season, the waters of the rivers in the area are muddy. The muddy nature of the waters is as a result of sediments that are eroded into the rivers. In the dry season, due to a decrease in precipitation, the level of the rivers falls and there is a marked decrease in flow rates. The surface of the waters appears less muddy as the erosive processes occurring during this period are not as intense as in the rainy season (Egboka and Okpoko 1999). 


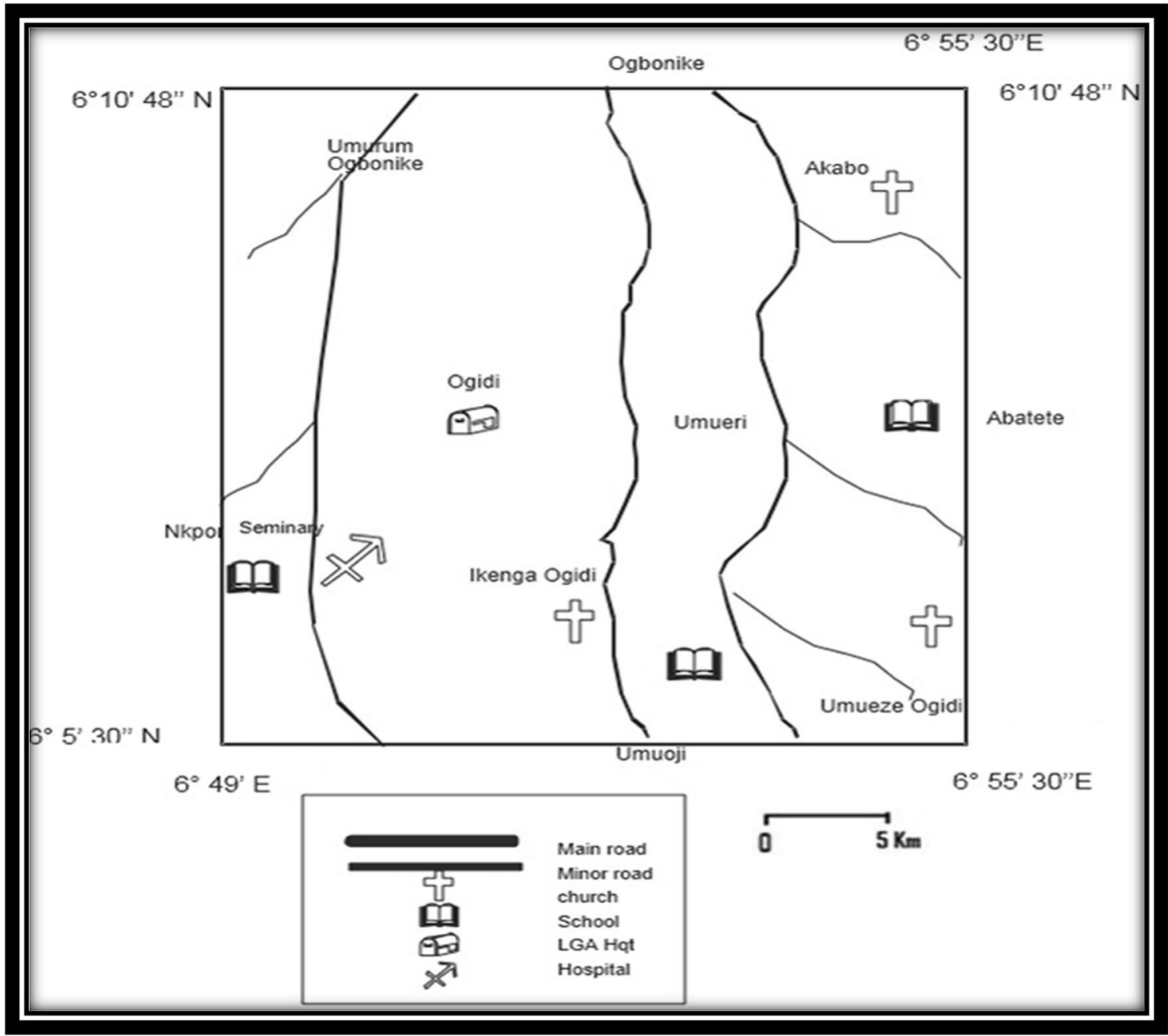

Fig.1 Location map of the study area

Table 1 Summary of the geology of Anambra State

\begin{tabular}{|c|c|c|}
\hline Formation name & $\begin{array}{l}\text { Maximum approximate } \\
\text { thickness }(\mathrm{N})\end{array}$ & Characteristics \\
\hline Holecene alluvium & 90 & Loose sands with quartz \\
\hline $\begin{array}{l}\text { Miocene-Pleistocene } \\
\text { Benin Formation }\end{array}$ & 200 & Thick yellow, white sands, with interbedded pebbles, clays and sandy clay \\
\hline $\begin{array}{l}\text { Oligoocene-Miocene } \\
\text { Ogwashi-Asaba Formation }\end{array}$ & 300 & Alternation of seams of lignite, clays and shales \\
\hline Eocene Ameki Formation & 1460 & Lignite and sandstone \\
\hline Paleocene Imo Shale & 1200 & $\begin{array}{l}\text { Thick clayey shale, fine textured, dark grey to bluish grey, with occasional } \\
\text { admixture of clay, ironstones and thin sandstone bands }\end{array}$ \\
\hline
\end{tabular}

\section{Materials and method}

The Schlumberger configuration was chosen over Wenner configuration for this study. This is because the Schlumberger array of electrodes provides high signal-to-noise ratios, good resolution of horizontal layers and good depth sensitivity (Ward 1990). In the Schlumberger configuration (Fig. 3), $\mathrm{C} 1$ and $\mathrm{C} 2$ are the current electrodes through which artificial currents are introduced into the ground, while $\mathrm{P} 1$ and $\mathrm{P} 2$ are the potential electrodes through which the 


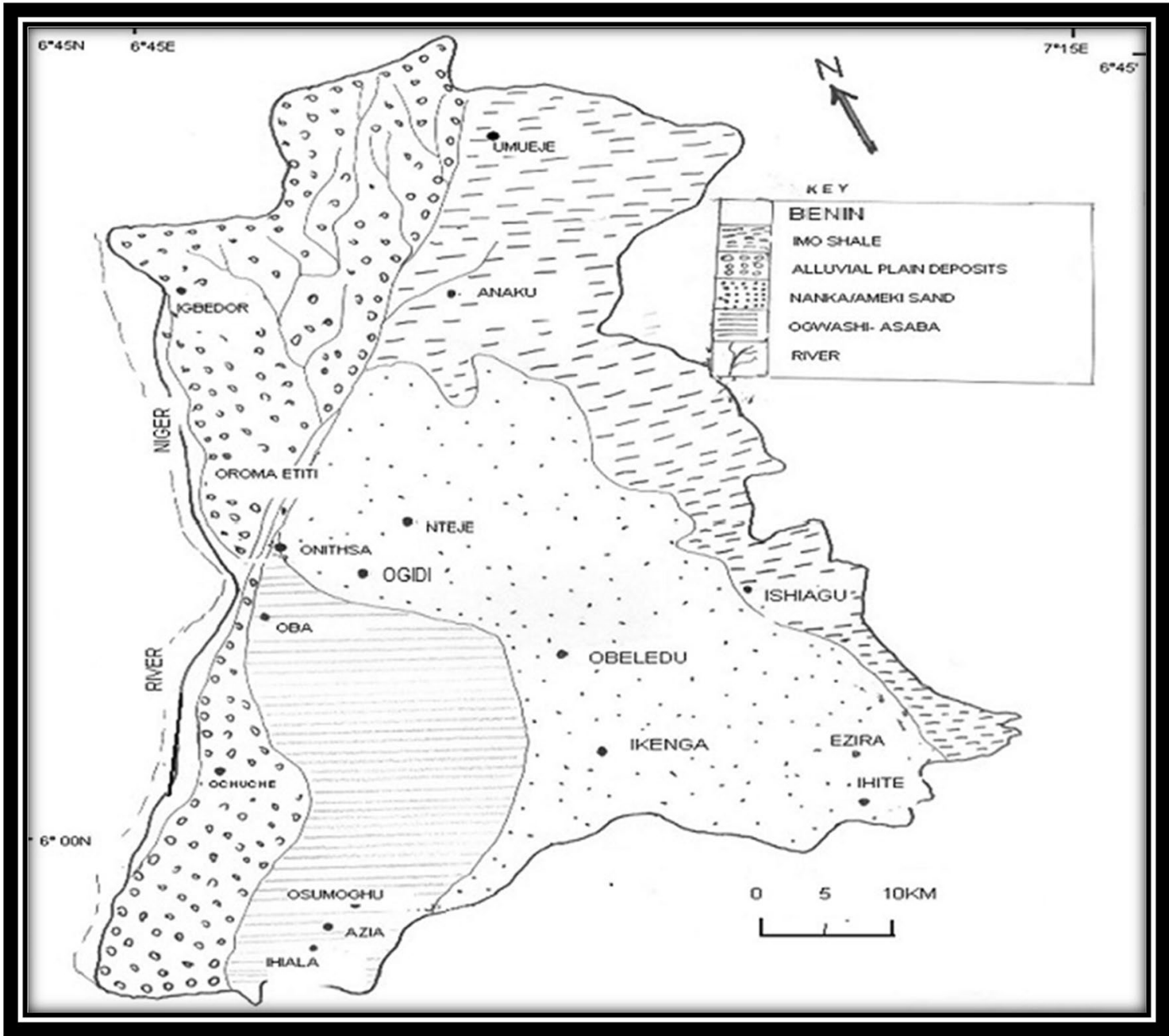

Fig. 2 Geological map of Anambra State (after Nfor et al. 2007)

Fig. 3 Schlumberger configuration

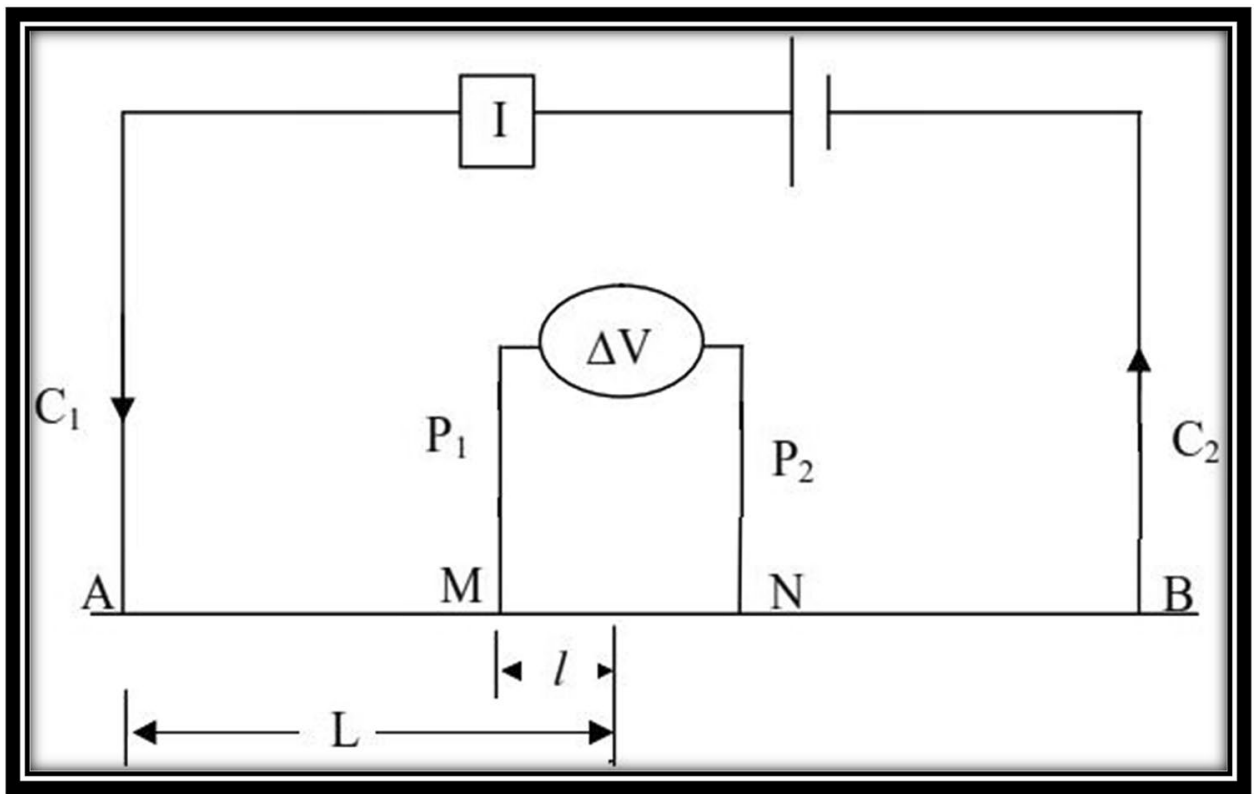


potential difference induced by the currents is measured. In this configuration, the potential electrodes are kept constant while current electrodes are moved about the fixed centre of the array. For Schlumberger configuration, apparent resistivity is as given in the equation below (Ogungbe et al. 2012)

$\rho_{a}=\pi\left\{\frac{\left\{\frac{\mathrm{AB}}{2}\right\}^{2}-\left\{\frac{\mathrm{MN}}{2}\right\}^{2}}{\mathrm{MN}}\right\} \frac{\mathrm{V}}{\mathrm{I}}$

where $A B / 2$ is half current electrode separation, $M N / 2$ is half potential electrode separation.

Variation in electrical conductivity of the ground was investigated using electrical resistivity soundings. The Schlumberger array of electrical resistivity adopted in this study was used to delineate the vertical variations of resistivity at different depths. The materials used for data collection are ABEM terrameter (SAS 1000), four stainless metal stakes used as electrodes, booster, cables for current and potential electrodes, three hammers, measuring tapes and cell phones for long distance communication during measurement. These materials were gotten from Rural Water Supply and Sanitation Agency (RUWASSA), Ministry of Public Utilities, Awka.

Similarly, the interpretation of electrical resistivity data with the ultimate aim of determining the thickness and the true resistivity of the individual layers in the ground was carried out by means of computer iteration using WinRESIST version 1.0. The curves obtained were matched using master curves and were inspected to determine the number and nature of the layers. The results of the curve matching (layer resistivity and thickness) were fed into the computer as a starting model in an iterative forward modelling technique using the WinRESIST software. This is to vindicate the correlation of the field curve and the theoretical curve (Ogungbe et al. 2012).

The geo-electric sections obtained from VES and lithology (borehole) logs were correlated and compared to obtain the geologic sections.

\section{Data collection}

Thirteen vertical electrical sounding (VES) data were collected using a maximum current electrode separation of $\mathrm{AB} / 2$ of $500 \mathrm{~m}$. Apparent resistivity was obtained automatically by converting the resistance $(\mathrm{R})$ values of the ground obtained in the field using Eq. (1). The terrameter is powered by a $12-\mathrm{V}$ dc battery. Current electrodes separation was increased at intervals during the soundings, while the potential electrodes separation was kept relatively fixed. The four electrodes used were arranged in a straight line with respect to the centre and were fixed deep into the ground to ensure good electrical contact. Furthermore, the area around the electrodes was made wet (in case of dry soil conditions), to enable better current penetration. This procedure was repeated for all the thirteen VES stations. Figure 4 shows a map of the study area showing the location of the thirteen VES points. The sounding curve for each sounding point was obtained by plotting the apparent resistivity values as ordinate against half current electrodes spacing $(\mathrm{AB} / 2)$.

\section{Results}

\section{Qualitative interpretation}

The first step in the interpretation of the resistivity sounding data was to classify the observed apparent resistivity curves into types. This classification is primarily made on the basis of the shapes of the curves. It was done by visual inspection of the sounding curves. A sound knowledge of the geology of the area under study and practical experience were needed in achieving good results. Borehole logs obtained from Ministry of Public Utilities, Awka, were used during the interpretation for comparison and correlations.

\section{Quantitative interpretation}

VES data were obtained at the 13 geo-electric sounding stations represented as VES 1-13.

\section{Geo-electric curve types}

Table 2 shows the curve types and the curve characteristics for the 13 VES points. The interpreted sounding curves within this study area have about five groups of curve types.

The sounding curves at VES 1 and 8 are of KH- curve type, the sounding curves at VES 2, 4, 5, 6 and 9 are of AK-curve type, VES 10,11, 12 and 13 are of HK-curve type while VES 3 and 7 are of HA and AA curve types, respectively. 


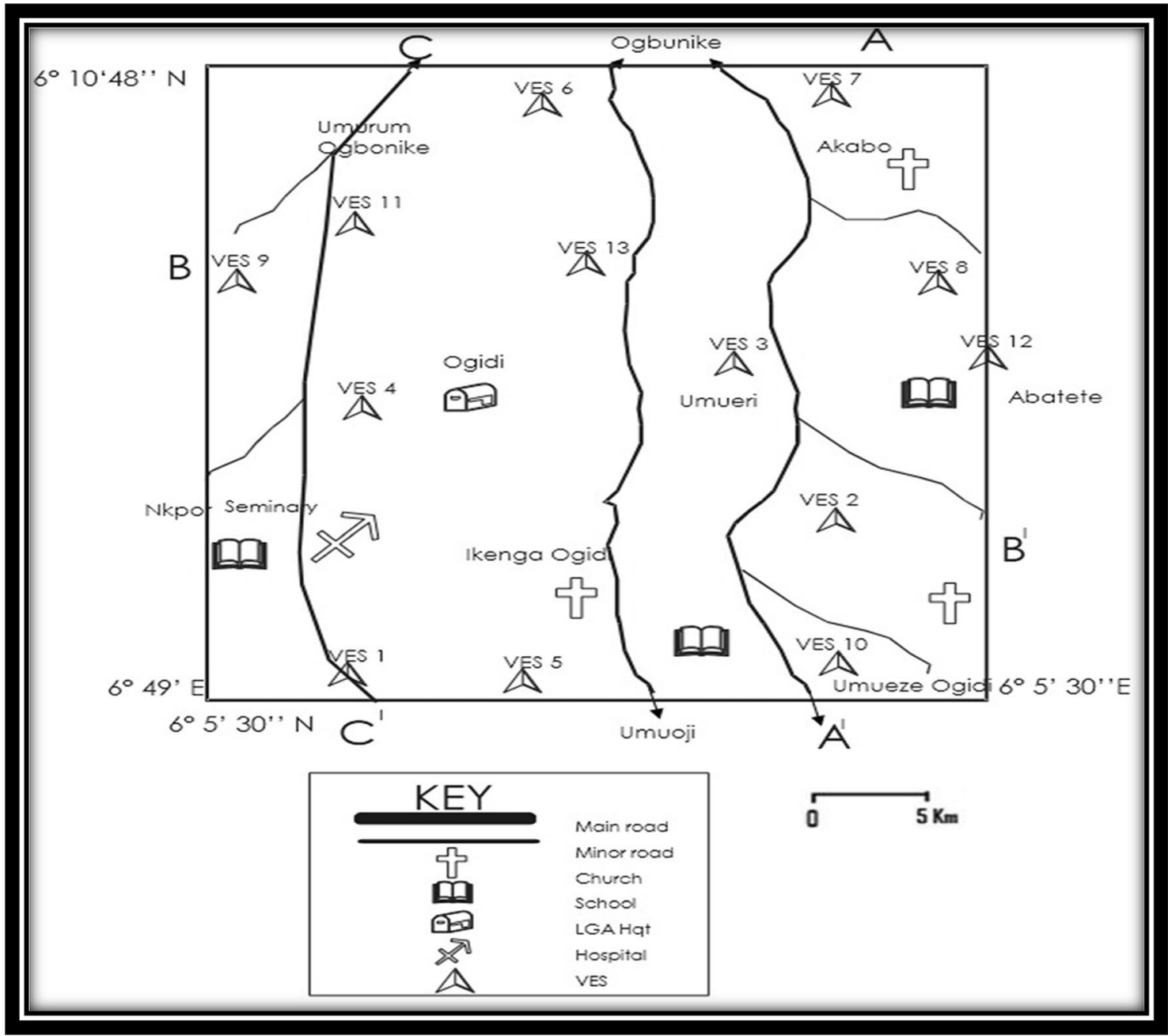

Fig. 4 Location map showing various VES points

Table 2 Analysis of curve types (after Compagnie 1963)

\begin{tabular}{llll}
\hline VES points & Curve type & Curve characteristics & $\begin{array}{l}\text { No of } \\
\text { geo-electric } \\
\text { layers }\end{array}$ \\
\hline 1 & KH & $\rho 1<\rho 2>\rho 3>\rho 4$ & 7 \\
2 & AK & $\rho 1<\rho 2>\rho 3>\rho 4$ & 6 \\
3 & HA & $\rho 1>\rho 2<\rho 3<\rho 4$ & 9 \\
4 & AK & $\rho 1<\rho 2<\rho 3>\rho 4$ & 7 \\
5 & AK & $\rho 1<\rho 2<\rho 3>\rho 4$ & 7 \\
6 & AK & $\rho 1<\rho 2<\rho 3>\rho 4$ & 9 \\
7 & AA & $\rho 1<\rho 2<\rho 3<\rho 4$ & 6 \\
8 & KH & $\rho 1<\rho 2>\rho 3>\rho 4$ & 6 \\
9 & AK & $\rho 1<\rho 2<\rho 3>\rho 4$ & 6 \\
10 & HK & $\rho 1>\rho 2<\rho 3>\rho 4$ & 6 \\
11 & HK & $\rho 1>\rho 2<\rho 3>\rho 4$ & 7 \\
12 & HK & $\rho 1>\rho 2<\rho 3>\rho 4$ & 6 \\
13 & HK & $\rho 1>\rho 2<\rho 3>\rho 4$ & 6 \\
\hline
\end{tabular}

\section{Interpretation of VES 8 (representing KH curve type of VES 1, 8)}

This sounding station contains six geo-electric layers (Fig. 5 and Table 3), with laterite being interpreted as the first layer with a resistivity of $352 \Omega \mathrm{m}$. The second layer which is interpreted as sandstone has a resistivity value of $3563 \Omega \mathrm{m}$ and a thickness of $1.29 \mathrm{~m}$. The third layer with a resistivity value of $12,600 \Omega \mathrm{m}$ and a thickness of $7.61 \mathrm{~m}$ is interpreted as dry sandstone. The next layer which is the layer of interest (aquifer) has a thickness of $31.8 \mathrm{~m}$, a resistivity of 5161 $\Omega \mathrm{m}$ and is interpreted as water-saturated sandstone. The fifth layer is interpreted as clayey sandstone with a resistivity of $1309 \Omega \mathrm{m}$. The last layer whose thickness could not be determined has a high resistivity value of $18,347 \Omega \mathrm{m}$ and is interpreted as sandstone. 
Fig. 5 Sounding curve for VES 8

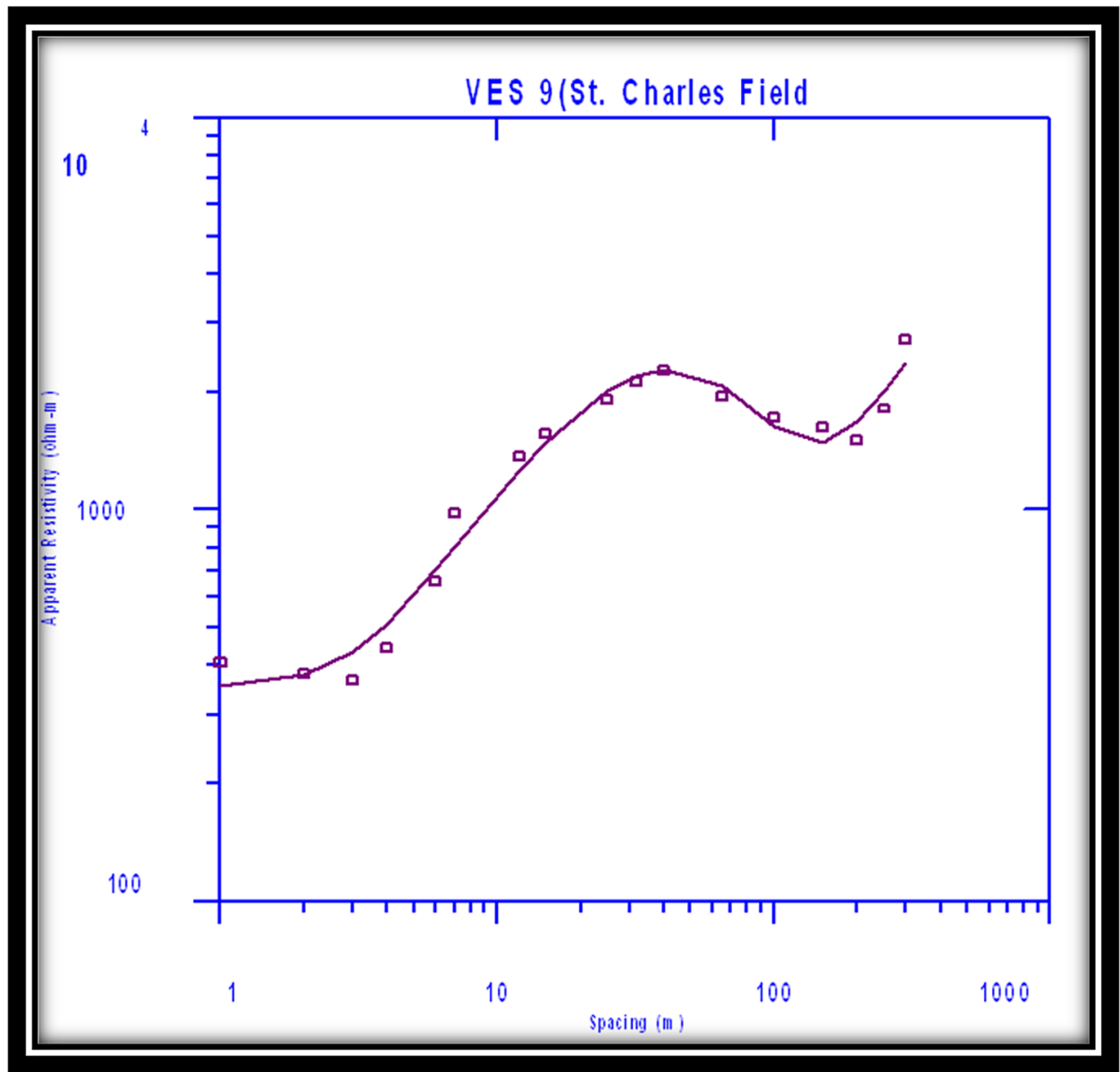

Table 3 Result of interpretation of VES 8

\begin{tabular}{lllll}
\hline Layer & $\begin{array}{l}\text { Apparent } \\
\text { resistivity } \\
(\Omega \mathrm{m})\end{array}$ & Thickness $(\mathrm{m})$ & Depth $(\mathrm{m})$ & Lithology \\
\hline 1 & 352 & 1.80 & 0 & Top soil (laterite) \\
2 & 3563 & 1.29 & 1.8 & Sandstone \\
3 & 12,600 & 7.61 & 3.09 & Dry sandstone \\
4 & 5161 & 31.80 & 10.7 & $\begin{array}{l}\text { Saturated sand- } \\
\text { stone }\end{array}$ \\
5 & 1309 & 39.40 & 42.5 & $\begin{array}{l}\text { Clayey sandstone } \\
6\end{array}$ \\
\hline
\end{tabular}

\section{Interpretation of VES 2 (representing AK-curve type of VES 2,4,5,6 and 9)}

This sounding curve (Fig. 6 and Table 4) has six geo-electric layers which comprise laterite, sandstone, clayey sandstone and water-saturated sandstone. The first layer with a resistivity value of $148.8 \Omega$ and a thickness of $0.78 \mathrm{~m}$ is interpreted as laterite. The second layer is interpreted as sandstone with a depth, thickness and resistivity values of $0.78 \mathrm{~m}, 5.63 \mathrm{~m}$ and 13,018 $\Omega \mathrm{m}$, respectively. The third layer which has a resistivity value of $6539 \Omega \mathrm{m}$ and a thickness of $13.35 \mathrm{~m}$ is interpreted as clayey sandstone. The next layer has a high resistivity value of $21,045 \Omega \mathrm{m}$ and is interpreted as sandstone. The fifth layer which has a thickness of $31.0 \mathrm{~m}$ and resistivity value of $9107 \Omega \mathrm{m}$ is interpreted as water-saturated sandstone (aquifer). The last layer with resistivity of $5674 \Omega \mathrm{m}$ and a depth of $87.34 \mathrm{~m}$ is interpreted as clayey sandstone.

\section{Interpretation of VES 10 (representing HK curve type of VES 10, 11, 12, and 13)}

This sounding location has six geo-electric layers (Fig. 7 and Table 5), showing laterite as the first layer with a resistivity of $76.2 \Omega \mathrm{m}$ and a thickness of $0.89 \mathrm{~m}$. The second layer with a resistivity of $9808 \Omega \mathrm{m}$ and a thickness of $3.32 \mathrm{~m}$ is interpreted as sandstone. The layer after the second layer has a thickness of $1.89 \mathrm{~m}$ and a depth of $4.21 \mathrm{~m}$ and is interpreted as clayey sandstone. The fourth layer which has a very high resistivity of $18,656 \Omega \mathrm{m}$ and a depth of $6.10 \mathrm{~m}$ is interpreted as sandstone. The layer of interest is the fifth, having a resistivity value of $4190 \Omega \mathrm{m}$ and a thickness of $42.6 \mathrm{~m}$, and is interpreted as water-saturated sandstone. The last layer 
Fig. 6 Sounding curve for VES 2

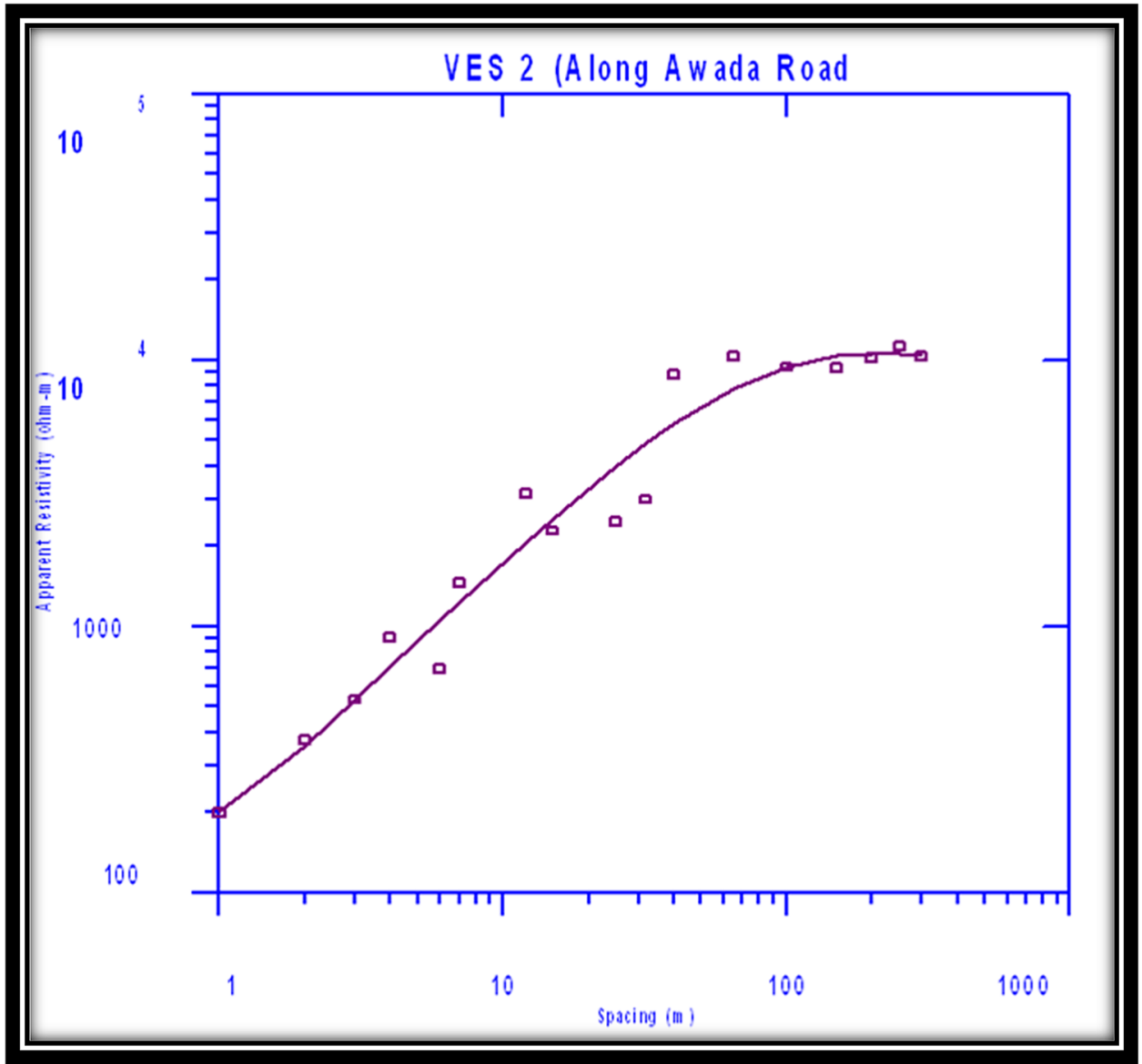

Table 4 Result of interpretation of VES 2

\begin{tabular}{lllll}
\hline Layer & $\begin{array}{l}\text { Apparent } \\
\text { resistivity } \\
(\Omega \mathrm{m})\end{array}$ & Thickness $(\mathrm{m})$ & Depth $(\mathrm{m})$ & Lithology \\
\hline 1 & 148.8 & 0.78 & 0 & Top soil (laterite) \\
2 & 13,018 & 5.63 & 0.78 & Sandstone \\
3 & 6539 & 13.35 & 6.41 & Clayey sandstone \\
4 & 21,045 & 15.92 & 19.76 & Sandstone \\
5 & 9107 & 31.0 & 35.68 & $\begin{array}{l}\text { Saturated sand- } \\
\text { stone } \\
\text { Clayey sandstone }\end{array}$ \\
6 & 5674 & & 66.68 & Clay \\
\hline
\end{tabular}

whose thickness could not be determined is interpreted as shale with a resistivity of $189 \Omega \mathrm{m}$.

\section{Interpretation of VES 7 (representing HA curve type of VES 3,7 )}

Six geo-electric layers were encountered in this sounding point (Fig. 8 and Table 6). The first layer has a thickness of $1.26 \mathrm{~m}$ and is interpreted as laterite. The second layer with a resistivity of $3478 \Omega \mathrm{m}$ and a thickness of $1.88 \mathrm{~m}$ is interpreted as sandstone. The third layer with a thickness of $9.36 \mathrm{~m}$ and a resistivity of $12,767 \Omega \mathrm{m}$ is interpreted also as sandstone. The fourth layer which is the layer of interest (aquifer) has a resistivity value of $3438 \Omega \mathrm{m}$ and a thickness of $22.3 \mathrm{~m}$ and is interpreted as water-saturated sandstone. The next layer is interpreted as clayey sandstone, having a resistivity of $1577 \Omega \mathrm{m}$ and a depth of $34.80 \mathrm{~m}$. The last layer is interpreted as shale and has a resistivity of $1228 \Omega \mathrm{m}$. 
Fig. 7 Sounding curve for VES 10

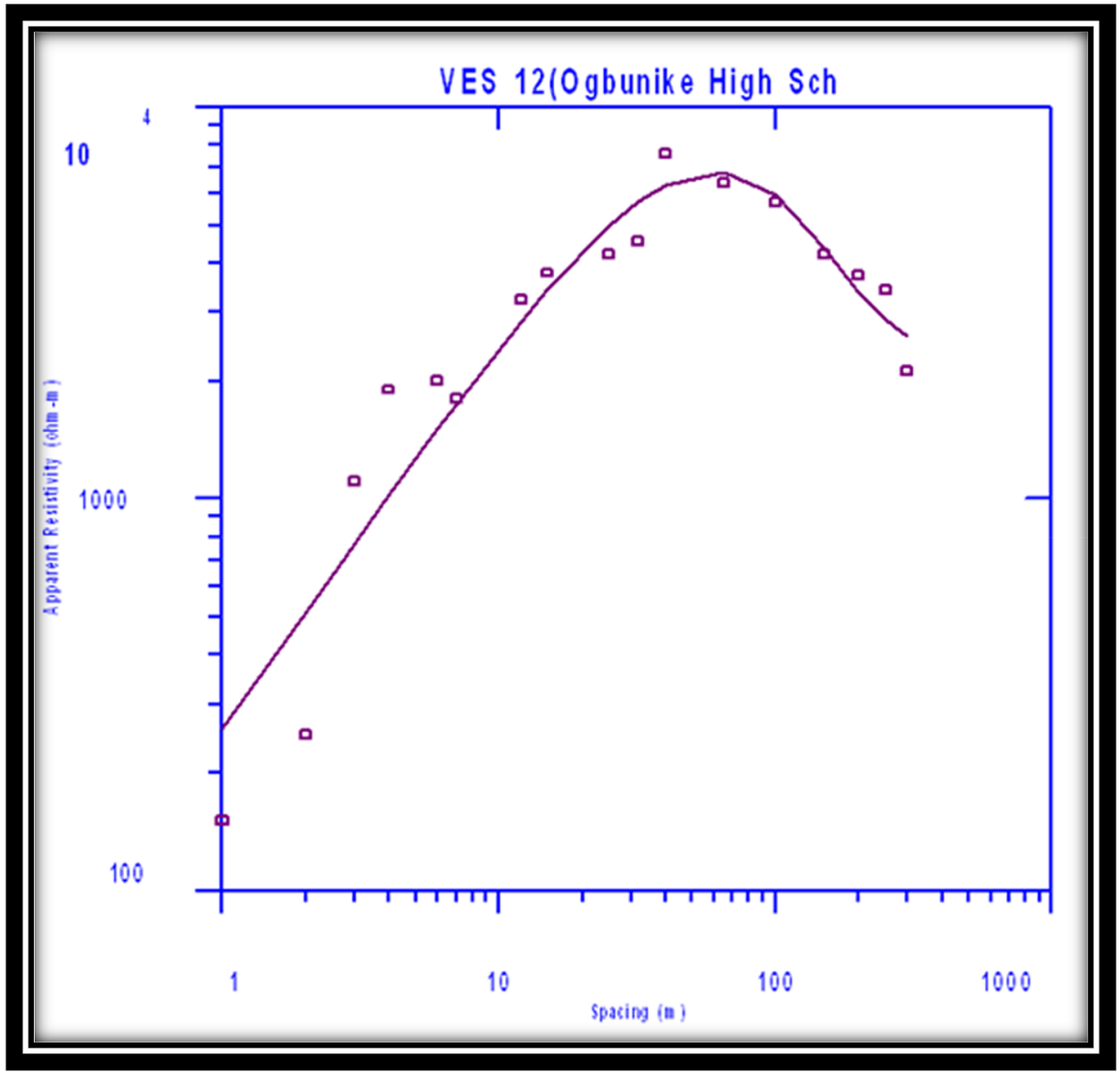

Table 5 Result of interpretation of VES 10

\begin{tabular}{lllll}
\hline Layer & $\begin{array}{l}\text { Apparent } \\
\text { resistivity } \\
(\Omega \mathrm{m})\end{array}$ & Thickness $(\mathrm{m})$ & Depth $(\mathrm{m})$ & Lithology \\
\hline 1 & 76.2 & 0.89 & 0 & Top soil (laterite) \\
2 & 9808 & 3.32 & 0.89 & Sandstone \\
3 & 2107 & 1.89 & 4.21 & Clayey sandstone \\
4 & 18,656 & 36.6 & 6.1 & Sandstone \\
5 & 4190 & 42.6 & 42.7 & $\begin{array}{l}\text { Saturated sand- } \\
\text { stone } \\
6\end{array}$ \\
& 189 & & 85.3 & Shale \\
\hline
\end{tabular}

\section{Geo-electric correlation along different profiles}

Existing borehole log near the vicinity of VES 1 and VES 10 was correlated with the geo-electric sections derived from VES 1 and 10 as shown in Fig. 9. This comparison showed similar layering between the VES-modelled sections and the existing litholog A.

In order to thoroughly investigate the thickness of various aquifers, geo-electric correlation was drawn along three profiles. The profiles were labelled AA', BB' and CC' respectively. 
Fig. 8 Sounding curve for VES 7

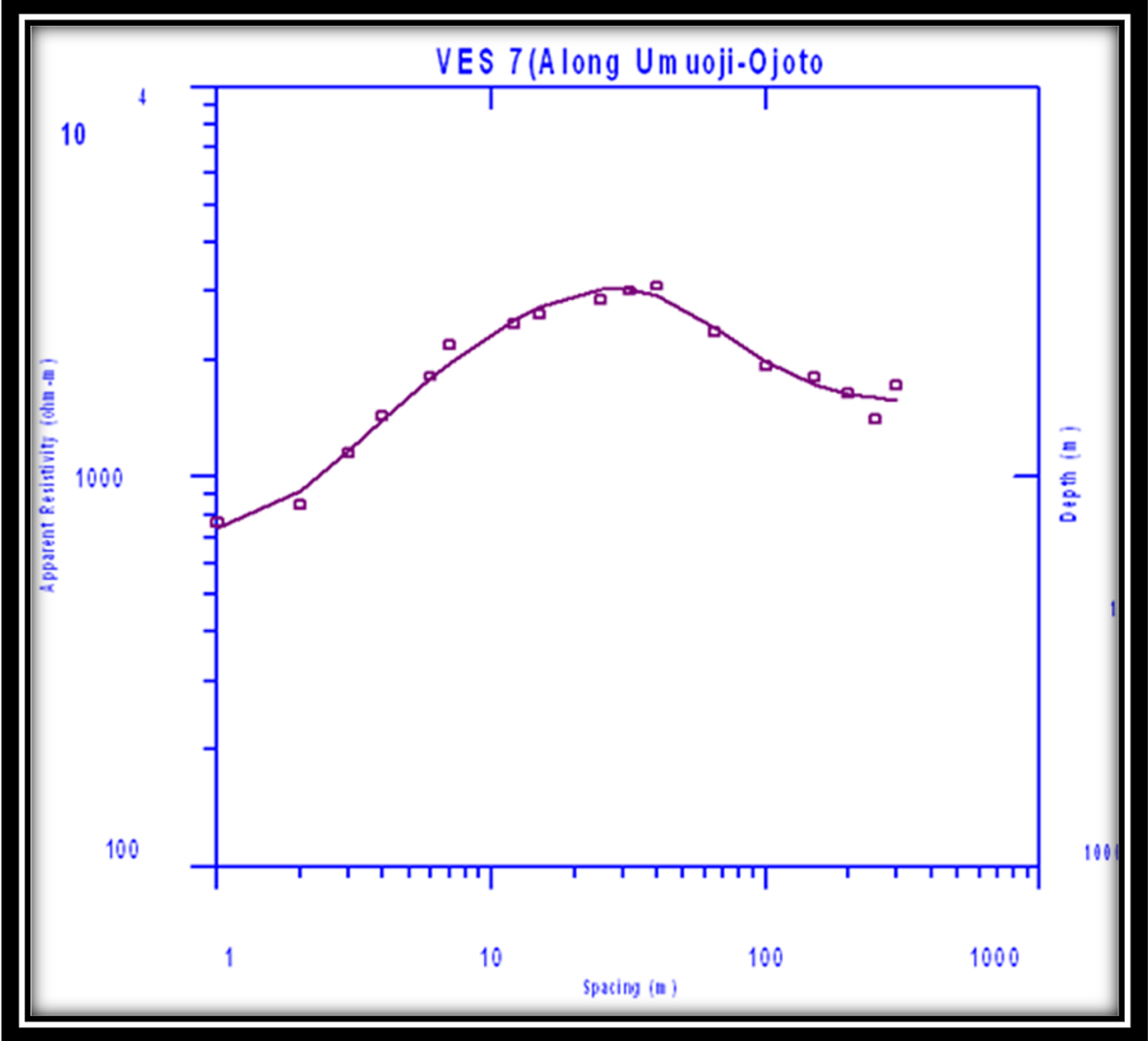

Table 6 Result of interpretation of VES 7

\begin{tabular}{lllll}
\hline Layer & $\begin{array}{l}\text { Apparent } \\
\text { resistivity } \\
(\Omega \mathrm{m})\end{array}$ & Thickness $(\mathrm{m})$ & Depth $(\mathrm{m})$ & Lithology \\
\hline 1 & 694.2 & 1.26 & 0 & Top soil (laterite) \\
2 & 3478 & 1.88 & 1.26 & Sandstone \\
3 & 12,767 & 9.36 & 3.14 & Sandstone \\
4 & 3438 & 22.3 & 12.5 & $\begin{array}{l}\text { Saturated sand- } \\
\text { stone }\end{array}$ \\
5 & 1577 & 26.4 & 34.8 & Clayey sandstone \\
6 & 1228 & & 61.2 & Shale \\
\hline
\end{tabular}

\section{VES points along profile $A A^{\prime}$}

AA' is a geo-electric profile drawn in the North-South direction. The VES points along this profile are VES 7, 2 and 10, covering a distance of about $7 \mathrm{~km}$. The VES points have six geo-electric layers each. VES 2 is an AK type, VES 10 is a HK type and VES 7 is an AA type. VES 2, VES 10 and VES 7 have aquifer thickness of $31.0 \mathrm{~m}, 42.6 \mathrm{~m}$ and $22.3 \mathrm{~m}$, respectively. Along this profile, VES 10 holds the best prospect for sustainable groundwater development (Fig. 10). 


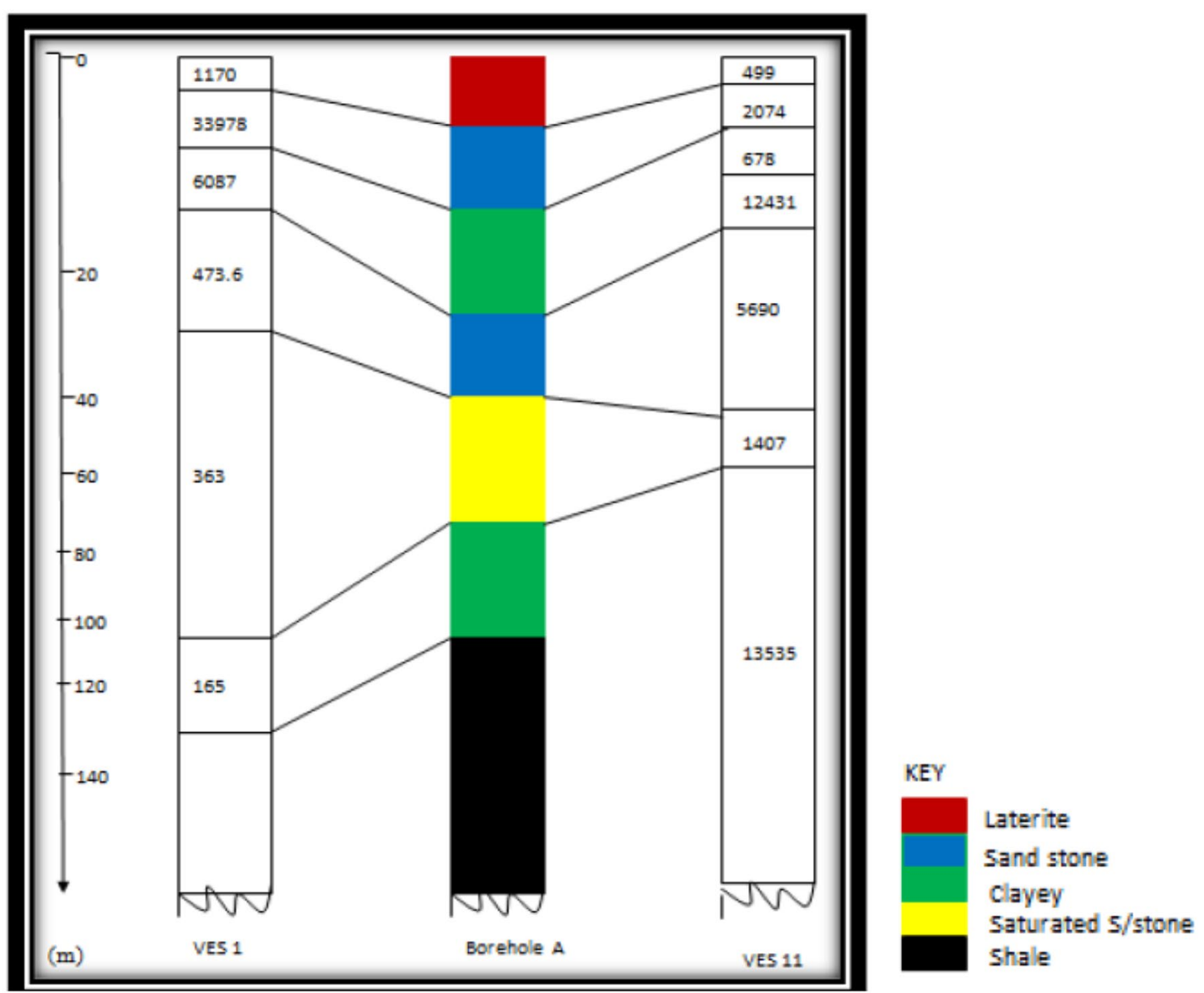

Fig. 9 Comparison of borehole log A with VES 1 and 11

\section{VES Points along profile BB'}

BB' is a profile drawn in the Northwest-Southeast direction. The VES points along this profile are VES 9, 4 and 2, and it covers a distance of about $6.5 \mathrm{~km}$. VES 2 and 9 have six geo-electric sections each, while VES 4 has seven geoelectric sections. The VES curves are of AK type. VES 2 has an aquifer thickness of $31.0 \mathrm{~m}$, VES 4 an aquifer thickness of $16.87 \mathrm{~m}$ while VES 9 has an aquifer thickness of $39.4 \mathrm{~m}$. Along the profile as shown in Fig. 11, VES 9 is the best area to site a borehole because of the highest value of aquifer thickness.

\section{VES points along profile CC'}

$\mathrm{CC}^{\prime}$ is a profile drawn in the North-South direction. The VES points along this profile are VES 11, 4, 5 and 1. The VES points have seven geo-electric sections each. VES 1 is a KH type, VES 4 and 5 are AK-type while VES 11 is a HK type. The thickness of aquifer for VES 1 is $72.5 \mathrm{~m}$ while for VES 11, 4 and 5, the thicknesses of aquifer are $6.5 \mathrm{~m}$, $16.87 \mathrm{~m}$ and $36.5 \mathrm{~m}$, respectively. VES 1 holds the best prospect for sustainable groundwater development along this profile because of the high thickness value (Fig. 12). 

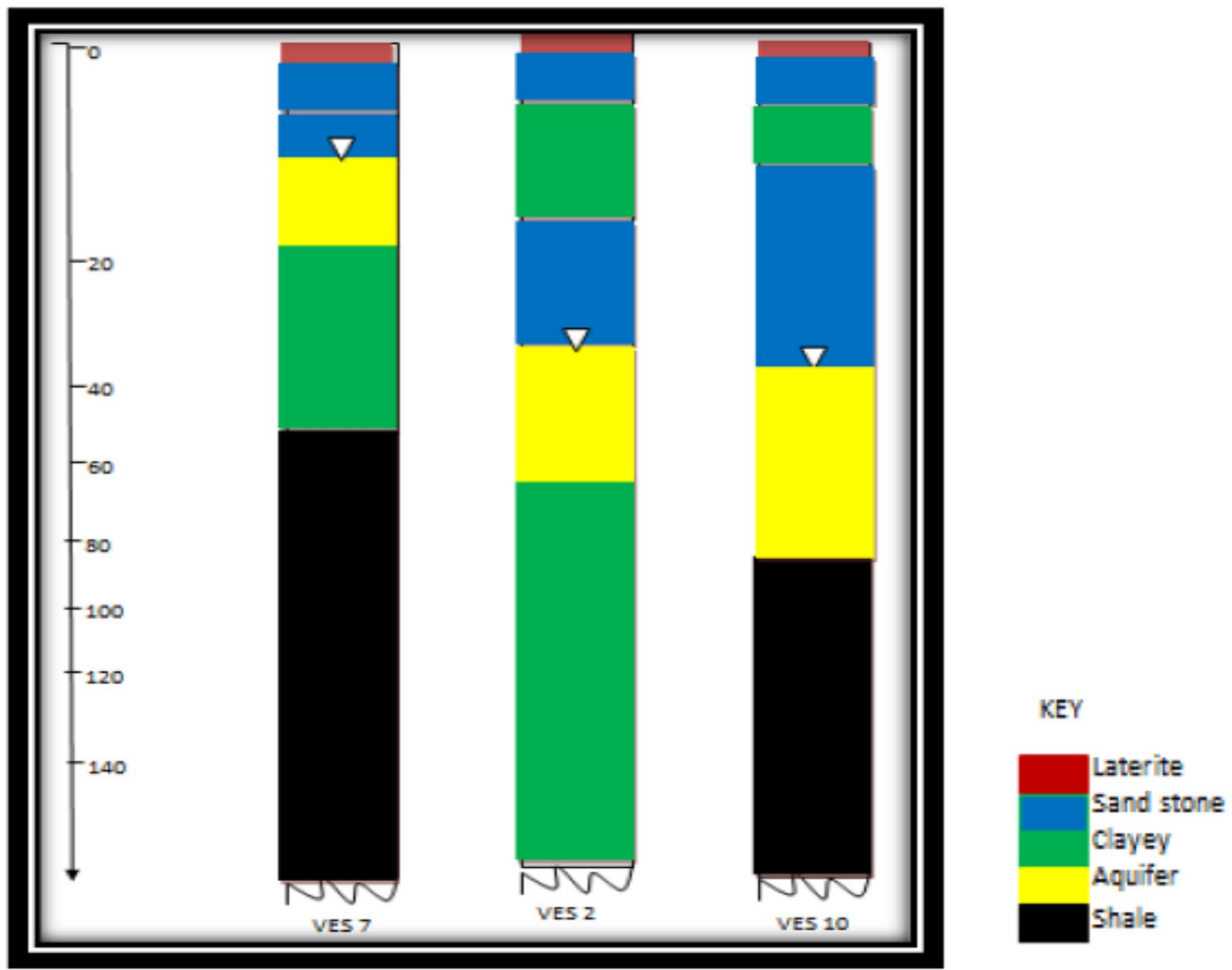

Fig. 10 Geo-electric correlation along profile AA'

\section{Discussion}

The geophysical method used in the study area has greatly assisted in evaluating the various aquifers, aquifer parameters using vertical electrical sounding techniques. The results obtained have shown a close semblance with results obtained from borehole logs obtained from the Ministry of Public Utilities Awka. Table 7 shows the summary of the aquifer parameters at the various locations across the study area. The results obtained are related to the work of Okparaeze
(2011) that carried out geophysical survey in Nnokwa and Alor using vertical electrical sounding (VES) technique to investigate groundwater potentials (depth to aquifer in Nnokwa varied from $27.0 \mathrm{~m}$ to $82.1 \mathrm{~m}$ while in Alor it varied from $34.3 \mathrm{~m}$ to $49.3 \mathrm{~m}$, respectively). The results of the VES data have aided in delineating the geo-electric sections of the area under investigations. The results revealed a minimum of six and maximum of nine geo-electric sections underlying various VES stations. The VES results also revealed that the resistivity of the water-saturated sandstone (aquifer) at 


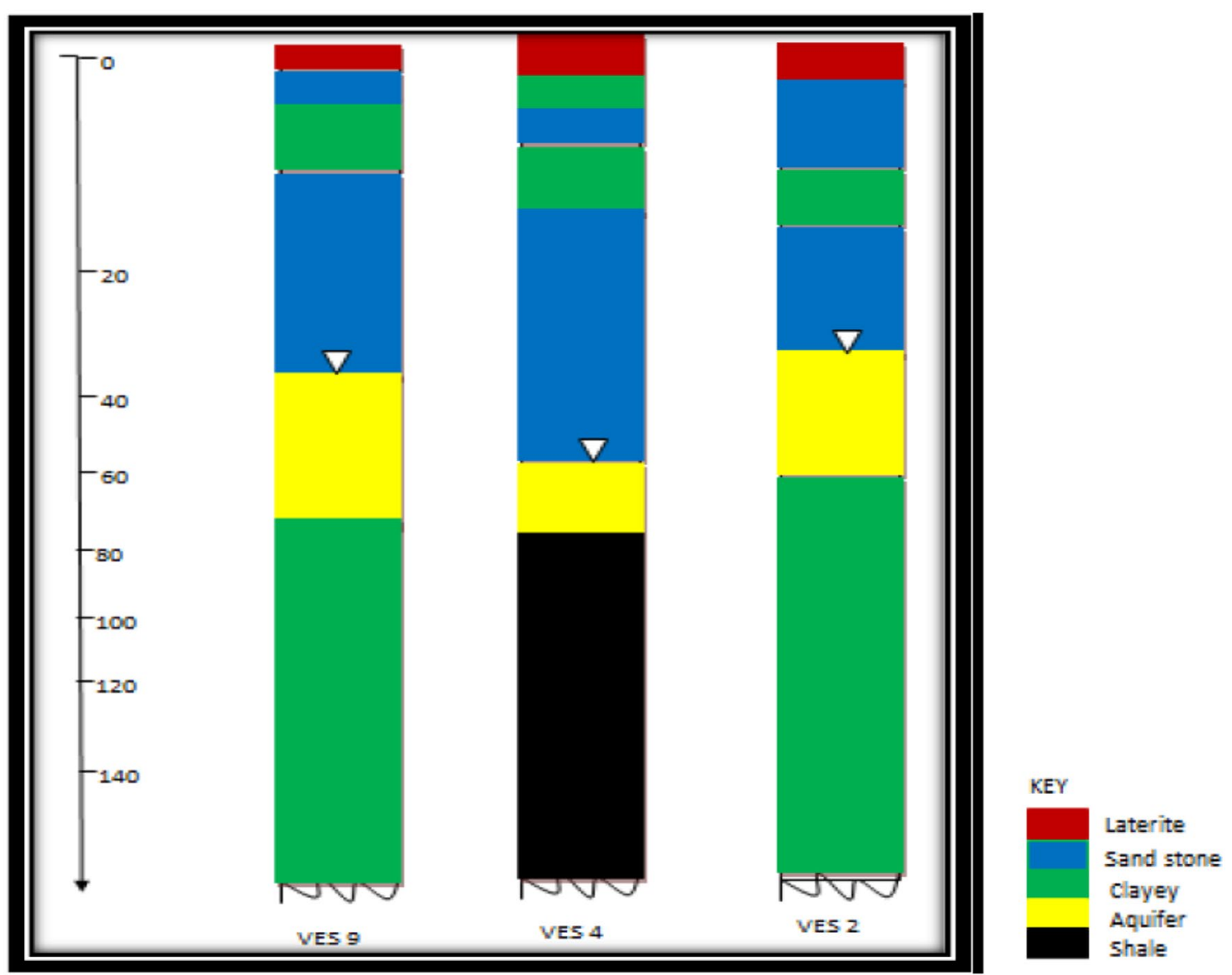

Fig.11 Geo-electric correlation along profile BB

the various stations varies from as low as $363 \Omega \mathrm{m}$ to as high as $9107 \Omega \mathrm{m}$; thickness of the aquifer varies from a value of $6.5 \mathrm{~m}$ at VES 11 to a value of $72.5 \mathrm{~m}$ at VES 1 . The geologic sections revealed that the first layer for the various soundings is composed of laterite. The second to the last layer at the various soundings stations contain water-saturated sandstone (aquifer) except VES 1, 7, 8 and 11 where it is at the third to the last layer. Furthermore, the results revealed that the aquifer is shallowest around Ogidi (VES 7 and 8) with values of $12.70 \mathrm{~m}$ and $10.70 \mathrm{~m}$, and deepest around Obosi (VES
2 and 13) with values of $118.66 \mathrm{~m}$ and $75.10 \mathrm{~m}$, respectively. Aquifer characteristics of hydraulic conductivity and transmissivity were established with hydraulic conductivity values ranging from 0.001 to $0.066 \mathrm{~m} /$ day while transmissivity values ranged from 0.006 to $4.79 \mathrm{~m}^{2} /$ day. From the calculated transmissivity values, it is seen that VES 1 has the highest transmissivity value. 


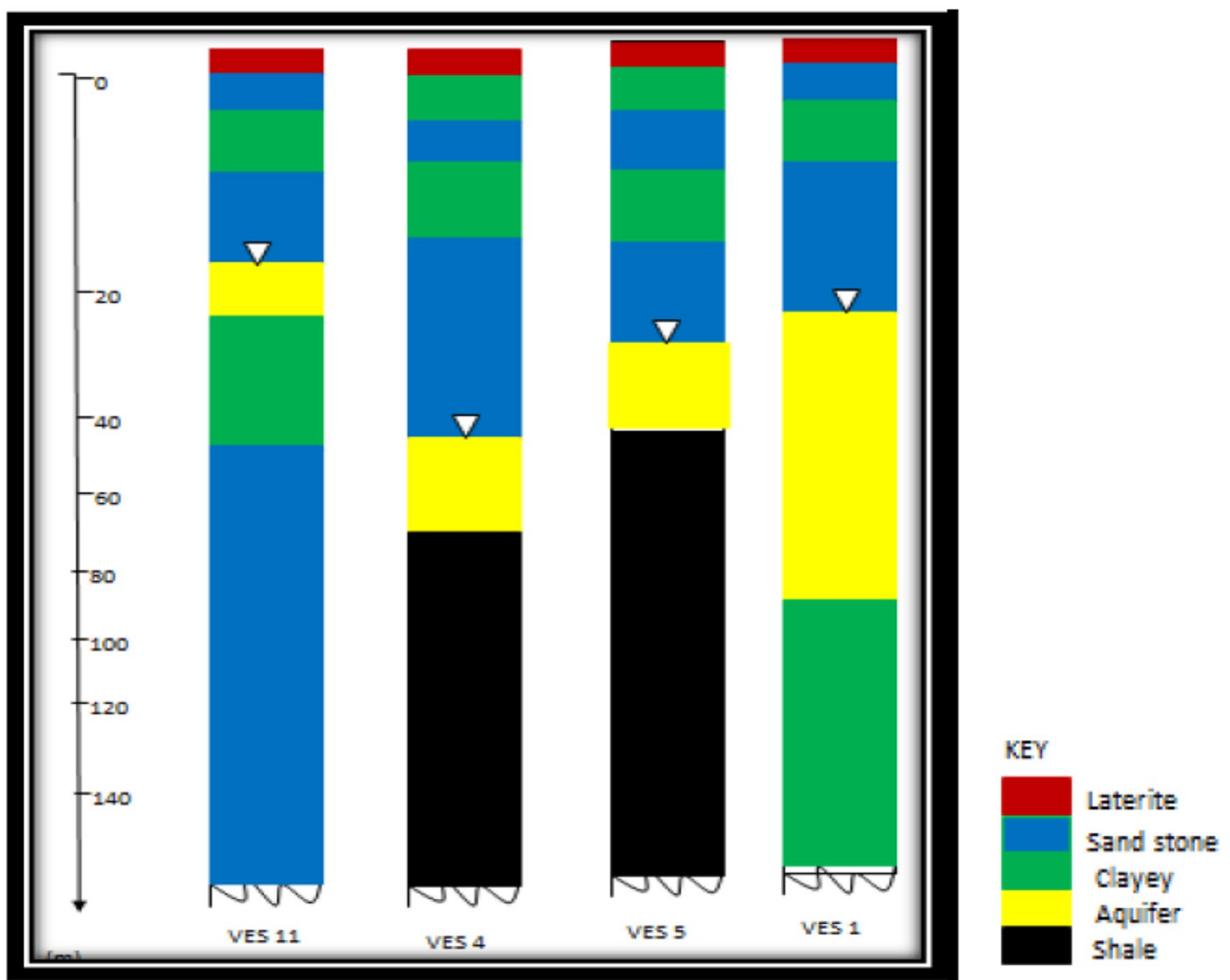

Fig.12 Geo-electric correlation along profile CC'

Table 7 Aquifer parameters at the various locations across the study area

\begin{tabular}{|c|c|c|c|c|c|c|}
\hline VES No & Location & $\begin{array}{l}\text { Aquifer } \\
\text { resistivity } \\
(\Omega \mathrm{m})\end{array}$ & Depth to water (m) & $\begin{array}{l}\text { Aquifer } \\
\text { thickness } \\
\text { (m) }\end{array}$ & $\begin{array}{l}\text { Hydraulic } \\
\text { conductivity }(\mathrm{m} / \\
\text { day) }\end{array}$ & $\begin{array}{l}\text { Transmissiv- } \\
\text { ity }\left(\mathrm{m}^{2} / \text { day }\right)\end{array}$ \\
\hline 1 & Community. Primary School Umuoji & 363 & 30.50 & 72.50 & 0.066 & 4.79 \\
\hline 2 & Umueze Ogidi & 9107 & 35.68 & 31.00 & 0.002 & 0.08 \\
\hline 3 & Iyienu 1 Ogidi & 1108 & 118.66 & 16.34 & 0.021 & 0.35 \\
\hline 4 & Iyienu 2 Ogidi & 3418 & 63.86 & 16.87 & 0.007 & 0.12 \\
\hline 5 & Building material market, Ogidi & 5116 & 27.60 & 36.50 & 0.004 & 0.17 \\
\hline 6 & St Paul Church, Ogidi & 6412 & 53.31 & 16.25 & 0.003 & 0.06 \\
\hline 7 & Along Umuoji Ojoto Road & 3438 & 12.50 & 22.30 & 0.006 & 0.16 \\
\hline 8 & St Charles's field, Ogidi & 5161 & 10.70 & 31.80 & 0.005 & 0.15 \\
\hline 9 & Behind St Barnabas Church, Ogbunike & 4826 & 42.50 & 39.40 & 0.005 & 0.20 \\
\hline 10 & Ogbunike High School & 4190 & 42.70 & 42.60 & 0.006 & 0.24 \\
\hline 11 & Ikenga Ogidi & 5690 & 26.70 & 6.50 & 0.001 & 0.01 \\
\hline 12 & Seminary Field, Nkpor & 6744 & 53.20 & 40.80 & 0.001 & 0.06 \\
\hline 13 & Opposite Holy Trinity Catholic Church, Ogidi & 6009 & 75.10 & 26.90 & 0.003 & 0.10 \\
\hline
\end{tabular}




\section{Conclusion}

The research work has provided information on the depth and the thickness of the aquifer units in the study area. This information will greatly assist in the development of an effective water scheme for the area. Based on all the findings made and the interpretations of the VES data, VES 1 (Community Primary School Umuoji) has been chosen as the most viable location for the development of groundwater resources in the study area. The thickness $(72.50 \mathrm{~m})$ and resistivity $(363 \Omega \mathrm{m})$ of the aquifer were obtained at this location. This area seems to satisfy necessary conditions that will guarantee an appreciable quantity of water for sustainable development. Conclusively, it should be noted that aquifer layers were encountered in all the sounding locations, which shows that the study area has a very good groundwater potential.

Funding The authors received no specific funding for this work.

\section{Declarations}

Conflict of interest None to declare.

Open Access This article is licensed under a Creative Commons Attribution 4.0 International License, which permits use, sharing, adaptation, distribution and reproduction in any medium or format, as long as you give appropriate credit to the original author(s) and the source, provide a link to the Creative Commons licence, and indicate if changes were made. The images or other third party material in this article are included in the article's Creative Commons licence, unless indicated otherwise in a credit line to the material. If material is not included in the article's Creative Commons licence and your intended use is not permitted by statutory regulation or exceeds the permitted use, you will need to obtain permission directly from the copyright holder. To view a copy of this licence, visit http://creativecommons.org/licenses/by/4.0/.

\section{References}

Bayowa GO, Olorunfemi MO, Ademilua OL (2014) A geoelectric assessment and classification of the aquifer systems in a typical basement complex terrain: case study of Ekiti State, Southwestern Nigeria. Res J Eng Appl Sci 3(1):55-60

Compagnie Generale de Geophysique (1963) Master curves for electrical sounding, 2nd, rev edn. European Association of Exploration Geophysicists, The Hague

Egboka BCE, Okpoko EI (1999) Conjunctive uses of water resources and management in Anambra State, Nigeria. Natural Appl Sci J $9(2): 2005$

Ekwe AC, Onu NN, Onuoha KM (2006) Estimation of aquifer hydraulic characteristics from electrical sounding data: the case of Middle Imo River Basin aquifers, Southeastern Nigeria. J Spatial Hydrol 6(2):121-132

Ezenwa UO (1998) Geological investigation of parts of Ogidi. Ministry of Public Utilities, Awka, p 113

Keary P, Brooks M (1991) An introduction to geophysical exploration, 2nd edn. Blackwall Scientific Publications, Oxford, p 254p

Madu CI (2009) Geoelectric sounding for predicting aquifer properties. Ministry of Public Utilities, Awka

Nfor BN, Olobaniyi SB, Ogala JE (2007) Extent and distribution of groundwater resources in parts of Anambra State. Appl Sci Environ Manage J 11(2):215-222

Ogungbe AS, Onori EO, Olaoye MA (2012) Application of electrical resistivity techniques in the investigation of groundwater contamination: a case study of Ile-Epo dumpsite, Lagos, Nigeria. Int J Geomatics Geosci 3(1):30-41

Okparaeze J (2011) Geoelectric investigations of Idemili South Local Government Area of Anambra State. Appl Sci Environm Manage J 9(6):111-119

Okwudike JJ (2012) Hydrological surveys in Onitsha by means of electrical soundings. Unpublished MSc thesis, Anambra State University, Uli

Reyment RA (1965) Aspects of the geology of Nigeria: the stratigraphy of the Cretaceous and Cenezoic deposits. University Press, Ibadan

Ugochukwu SC, Ezeokoli FO, Okoye PU (2015) The correlation between prevailing climatic conditions and prices of building materials-a case study of Anambra State, Nigeria. Int J Appl Sci Eng Res 4(5):856-870. https://doi.org/10.6088/ijaser.04087

Ward SH (1990) Resistivity and induced polarization methods. In: Ward SH (ed) Geotechnical and environmental geophysics, vol 1. Society of Exploration Geophysicists. https://doi. org/10.1190/1.9781560802785.ch61

Publisher's Note Springer Nature remains neutral with regard to jurisdictional claims in published maps and institutional affiliations. 